\title{
Design and Synthesis of 3-[1-oxo-(4-aryl-1-piperazinyl)alkyl]-N- (arylsulfonyl)-indoles as Potential Antagonists Agents on 5- HT6 Receptors
}

\author{
Recabarren-Gajardo*, G.; Espinosa-Bustos, C.; Hebel, D.; Meza, W.; Tapia, F.; \\ Zárate, A.; Lagos, C.F. \& Pessoa-Mahana, C.D. \\ Department of Pharmacy, Faculty of Chemistry, Pontificia Universidad Católica de Chile, Casilla 306,
} Santiago-22, Chile

*e-mail:grecabarren@uc.cl or ccespino@uc.cl

Keywords: 5-HT $T_{6}$ receptors, indoles, antagonists

\section{INTRODUCTION}

The $5-\mathrm{HT}_{6}$ receptor is the most recently identified and cloned member of the serotonin receptor family. Extensive research has shown that this receptor is expressed in brain regions known to be associated with learning and memory. ${ }^{1}$ Blockade of the $5-\mathrm{HT}_{6}$ receptor function has shown to specifically increase cholinergic and glutamatergic neurotransmission, improving cognition parameters in a number of rodent behavioral models. Given the fundamental role of both the acetylcholine and glutamate systems in cognitive processes, and their disturbance in memory dysfunction, $5-\mathrm{HT}_{6}$ receptors inhibitors may play a therapeutic role on the modulation of normal and/or dysfunctional memory. In this work we report the synthesis of a new series of $\mathrm{N}$-(arylsulfonyl)indoles compounds, targeted to $5-\mathrm{HT}_{6}$ receptor.

\section{RESULTS AND DISCUSSION}

The compounds were designed using a combined ligand and structure-based approach (Fig. 1). First, a virtual library of 1728 compounds was constructed based on the López-Rodríguez pharmacophore model. $^{2}$ The library was virtually screened against a $5-\mathrm{HT}_{6}$ receptor model using a pharmacophore hypothesis developed with very active ligands as filter. The best scoring compounds were selected for synthesis.

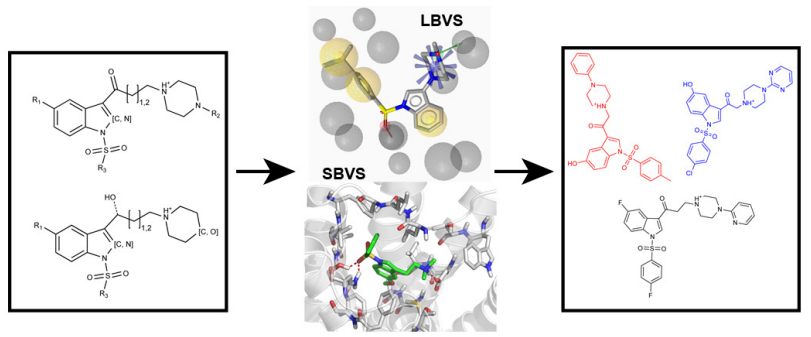

Figure 1. Combined ligand and structure-based virtual screening workflow used for compound synthesis prioritization.
In the following schemes the synthetic strategy is shown.

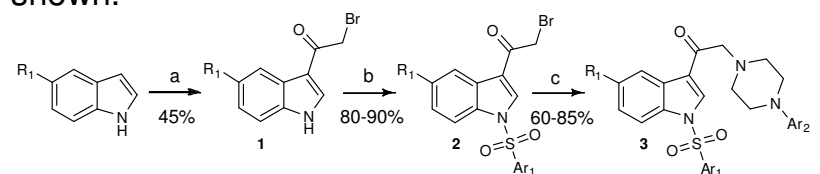

Scheme 1: a: i) anhydrous $\mathrm{ZnCl}_{2}$, dry $\mathrm{THF}, \mathrm{CH}_{3} \mathrm{MgBr}$, rt, ii) $\mathrm{BrCH}_{2} \mathrm{COCl}$, iii) $\mathrm{NH}_{4} \mathrm{Cl}$ sat.; b: $\mathrm{ArSO}_{2} \mathrm{Cl}, \mathrm{Et}_{3} \mathrm{~N}, \mathrm{DMAP}$, $\mathrm{CH}_{2} \mathrm{Cl}_{2}$, rt; c: Arylpiperazines, $\mathrm{K}_{2} \mathrm{CO}_{3}$, acetone.

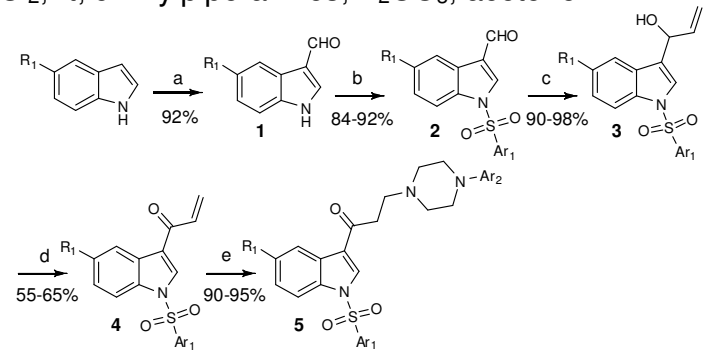

Scheme 2: a: i) $\mathrm{POCl}_{3} / \mathrm{N}, \mathrm{N}-\mathrm{DMF}, 0^{\circ} \mathrm{C}, 1 \mathrm{~h}$; ii) $\mathrm{H}_{2} \mathrm{O}$, $\mathrm{pH}$ 12; b: $\mathrm{ArSO}_{2} \mathrm{Cl}, \mathrm{Et}_{3} \mathrm{~N}$, DMAP, $\mathrm{CH}_{2} \mathrm{Cl}_{2}$, rt; c: i) VinylMgBr (1.2 eq)/ dry THF, rt, ii) $\mathrm{H}_{3} \mathrm{O}^{+}$; d: $\mathrm{MnO}_{2} / \mathrm{CH}_{2} \mathrm{Cl}_{2}, \mathrm{MgSO}_{4}$; e: Arylpiperazines, MW.

\section{CONCLUSION}

We have designed and synthetized a two new series of $\mathrm{N}$-arylsulfonylindoles targeting $5-\mathrm{HT}_{6}$ receptor and obtained the selected compounds in good yields. In order to evaluate their affinity and determine the pharmacological profile at this receptor, the compounds are currently being evaluated for their affinity for human $5-\mathrm{HT}_{6}$ receptor expressed in HEK-293T cells system.

\section{ACKNOWLEDGEMENTS}

Fondecyt Project Grant 1100493, Conicyt Bicentennial Project Research Grant SD-70 and Conicyt PhD fellows for financial support.

\section{REFERENCES}

${ }^{1}$ Liu, K.G. and Robichaud, A. J. Int. Rev. Neurobiol. 2010, 94, 1.

${ }^{2}$ López-Rodríguez, M. L. et al. J. Med. Chem. 2005, 48, 4216. 